\title{
Commercial Bank Money, Seigniorage, AND the MACROECONOMY
}

\author{
BiAgio BosSONE ${ }^{1}$ \\ Viale della Musica, 41 \\ 00144 Rome, Italy \\ E-mail: biagio.bossone@gmail.com \\ Rome, August 2018
}

\begin{abstract}
This article evaluates the macroeconomic implications of commercial bank seigniorage, which emerges from the commercial banks' power to create money in a fractional reserves regime. After evaluating the impact on aggregate output of commercial bank money relative to alternative exchange arrangements, the article identifies the determinants of commercial bank seigniorage and analyzes how equilibrium prices are determined in an economy where commercial banks extract seigniorage. The article also identifies the conditions under which commercial banks extract seigniorage, clarifies the relationship between seigniorage from commercial bank money creation and profits from pure financial intermediation, and shows how commercial bank seigniorage changes with different types of interbank payments settlement.
\end{abstract}

JEL Codes: E19, E20, E31, E40, E52, E58, E62, G21.

Key Words: Commercial banks, Interest rate, Money creation, Monetary circuit of production, Resource distribution, Seigniorage.

\footnotetext{
${ }^{1}$ Biagio Bossone, director, B.R.A.S.S. on Finance, Ltd.
} 


\section{INTRODUCTION}

Etymologically understood as the "right of the lord to mint money,"2 seigniorage is generally defined as the difference between the value of money and the cost to produce it, which accrues to the issuer of money. As noted by Buiter (2007), seigniorage has historically belonged to governments, which over the ages have appropriated real resources through the monopoly of the coinage.

Seigniorage, thus, is a special form of rent - or unearned income - that the state extracts from the economy by virtue of its power to issue money. It may by all means be conceptually assimilated to a tax, for it corresponds to a net transfer of real resources from the economy to the state.

In contemporary economies using fiat money, the monopoly of the issue of legal tender is assigned to an agency of the state - the central bank - which may operate under varying degrees of independence from government. ${ }^{3}$ The seigniorage on such money, thus, accrues to the issuing central bank, which then only partly return it to the state, after covering for its own operating costs and after assuring itself a (generous) profit.

Seigniorage, therefore, is inherently associated with the power to create money, irrespective of who exercises it. This is of critical importance as recognition is given to the fact that, over the years and in all contemporary economies, the power to create the largest fraction of the money used in transactions has been appropriated (somehow surreptitiously ${ }^{4}$ ) by commercial banks. By virtue of this power, and to the extent that

i. banks' marginal cost of extending loans by creating deposits is above that incurred by pure intermediaries that lend pre-existing resources

\footnotetext{
${ }^{2}$ According to the Oxford Dictionary, the word is a late middle English one deriving from old French "seigneur", a feudal lord (the lord of a manor).

${ }^{3}$ More specifically, the legal tender issued by central bank usually consists of banknotes and excludes the coins, which continue to be issued by the government's treasury. However, central banks are granted the power to issue the monetary instrument that is typically used to settle domestic interbank transactions (which represents the largest share of the economy's money). This instrument consists of money deposits held by commercial banks in special accounts held in the books of the central bank and called reserves, which can only be exchanged among banks.

${ }^{4}$ That is, outside of explicit law provisions and by exploiting deposit taking and lending regulations, as well explained by Werner (2014).
} 
ii. the money loaned by banks through deposit creation exceeds the amount that may be loaned, ceteris paribus, by pure intermediaries under the constraint posed by pre-existing resources, and

iii. the credit risk faced by banks and pure intermediaries (per unit of loaned resources) is identical, banks extract a net rent from the economy (seigniorage). ${ }^{5,6}$ Notice that since banks (unlike pure intermediaries) create ex nihilo the resources they lend, their loan interest income in excess of the valued added they contribute to the economy in terms of money services does not reflect any rewards for savers' thrift (as in classical economics) or any compensation for agents parting temporarily with liquidity (as in Keynes' liquidity preference theory).

\footnotetext{
${ }^{5}$ Recognizing that commercial banks receive seigniorage, however, should not conceal the importance of their money creation function - a point that was well noted by Joseph A. Schumpeter already in the early decades of the last century as he spoke of banks as the "ephors" of economic development (see the following footnote). Banks do add value to the economy by creating and allocating the public good money - that is needed to finance new activities. And much as issuing fiat money (instead of commodity money) affords greater elasticity to an economy that needs to grow, adopting a decentralized (versus centralized) money supply system based on commercial banking affords even greater elasticity to an economy that needs to allocate money to new initiatives. In both cases, the greater elasticity translates into a more flexible accommodation of the money supply to its dispersed demand, and at more favorable terms, than when money supply is determined by exogenous factors and managed by a central institution. Yet, that bank liabilities in the form of demand deposits are accepted as money by the public owes much to the contribution that each bank gives to public trust (based on its reputation as a solvent money lender and a reliable provider of payment services) as to external factor such as the role played by the institutions and policies that regulate banks and ensure their financial stability, the infrastructures supporting their activities, and the economies of scale (discussed below) involved in the payment system in which they operate - all factors that make the acceptance of bank liabilities as money the outcome of a collective process. Also, for the given benefits of an elastic supply of money, one may conceive of decentralized money supply regimes where the provision of money is separated from lending (Bossone and Sarr, 2002, 2003) and where seigniorage is thereby socialized (redistributed to the society).
}

${ }^{6}$ Schumpeter (1934) saw economic development as resulting from spontaneous and discontinuous changes in fact combinations brought about by the entrepreneurs. These changes altered an otherwise steady and ever identical circular flow of production whereby the same products would be produced every year in the same way and proportion, and each supply would be matched by an equal demand. Schumpeter realized that alterations to the circular flow could not happen without creation of new purchasing power and this, he thought, was the main function of banks. For him, bank money came into being in the process, and for the purpose, of granting credit to firms. He understood that banks did not confine themselves to transferring existing purchasing power: if they just did that, economic development would not be possible or would be much slower. Banks could add to the existing means of payments by lending promises to pay, and entrepreneurs could have access to bank money by mortgaging goods that they would then acquire with the borrowed purchasing power. Thus, total credit could be greater than if it had to be fully covered by commodity money. Schumpeter noted that bank credit allowed the economy to achieve a level of growth beyond what would be possible under commodity money. He as banks as able to create purchasing power in anticipation, and for the production, of new output: bank money was made of claims on services and goods that were yet to be produced. 
Commercial bank seigniorage is therefore a cost on the economy, and as such it should be analyzed. This article evaluates the potential macroeconomic implications of commercial bank seigniorage. More specifically, it investigates how commercial bank seigniorage impacts the real economy and identifies the channels through which seigniorage affects the economy's resource distribution process - both areas that have not yet received research attention.

The article is organized as follows. Section II reviews the literature on commercial bank seigniorage and explains how commercial banks extract seigniorage from the economy. Section III evaluates the impact of commercial bank money on aggregate output relative to alternative exchange arrangements in the context of rational agents (households, firms and banks); in particular, it considers the output effects associated with money creation and the seigniorage that goes with it. Section IV adopts a simple structuralist model with circuitist features to show how equilibrium prices are determined in a three-sector economy (with banks, firms and workers) where commercial banks extract seigniorage. Section V draws a number of economics and economic policy implications of commercial bank seigniorage, and Section IV concludes the article with a discussion of some critical counter-arguments to the arguments on commercial bank seigniorage. Finally, Appendix I studies the conditions under which commercial banks extract seigniorage and identifies analytically the determinants of commercial bank seigniorage; Appendix II clarifies the relationship between seigniorage from commercial bank money creation and profits from pure financial intermediation; and Appendix III shows how commercial bank seigniorage changes under different payment settlement rules.

\section{Commercial BANK Money ANd Seigniorage}

\section{A. Review of the Literature}

Thus far, the issue of commercial bank seigniorage has not received particular attention from research, perhaps owing to the fact that mainstream economics has recognized only recently the money creation power of commercial banks (see below). ${ }^{7}$ As a result,

\footnotetext{
${ }^{7}$ In a post titled Central Bankers: 'We're all Post-Keynesians now', Jesse Frederik suggests that central bankers may have grasped the reality of commercial bank money creation somewhat earlier than academics, who in their textbooks still to this day continue to subscribe to the conventional "money multiplier" story. See also the related post Who is right? Krugman or Keen or / and 9 Central Bank
} 
the literature on the subject is still quite limited. Early references on the origin of commercial bank seigniorage are Baltensperger and Jordan (1997) and Bossone (2000, 2001a,), while empirical studies have been done by Cardoso (2003), Arby (2006), Soldatos and Varelas (2015) and recently Bjerg et al. (cit.) and Macfarlane et al. (2017). In a forthcoming publication, Bossone et al. (2018) consider important theoretical and empirical aspects of seigniorage through the lenses of their newly proposed “Accounting View" of money.

This article's emphasis on bank loan interest rate as a cost element presents resemblances to the literature on the "cost channel" of monetary policy initiated by Barth and Ramey (2001) and further explored by Ravenna and Walsh (2006), Christiano et al. (2005), and Gaiotti and Secchi (2006), which analyze the impact of the nominal interest rate on the firms' marginal cost of production and the related implications for optimal monetary policy. Similarly, this article's predicted effect of the loan interest rate on inflation echoes the recent Neo-Fisherian proposition by, most prominent among others, Bullard (2015), Cochrane (2015), and Williamson (2016). However, neither branch of research investigates the rent nature of the interest rate on commercial bank money and how this rent impacts an economy's production and resource distribution. ${ }^{8}$

\section{B. Commercial Bank Seigniorage}

Unlike conventional (textbook) economics, which still considers banks as pure financial intermediaries, commercial banks are the primary creators of money in contemporary economies.

That banks create money in a fractional reserves regime by extending loans was recognized long ago by the post-Keynesian school (Moore 1978, 1983) and is one of the founding elements of the circuit theory of money, which studies the role of money

\footnotetext{
economists?. Interestingly, among central banker, Sir Mervyn King, former Governor of the Bank of England, addressing a conference of businesspeople once recognized that, "When banks extend loans to their customers, they create money by crediting their customers' accounts." (Speech to the South Wales Chamber of Commerce at The Millennium Centre, Cardiff on 23 October 2012).

${ }^{8}$ To be precise, Ravenna and Walsh derive aggregate output as a function of, inter alia, the interest rate on bank loans extended to finance firms' production. However, given the different scope of their analysis, they do not consider the interest rate on loans as a net subtraction of real resources from the economy due to its nature of seigniorage, nor how a change in such seigniorage would impact production and the distribution of income across the economy.
} 
in monetary production economies with historical time (Realfonzo 2012). ${ }^{9}$ In a stylized circuit process, the economy operates under a cash-in-advance constraint and banks advance through short-term loans the circulating capital that firms need in order to pay compensations to input owners during output production and in anticipation of output sales. ${ }^{10}$ As firms earn revenues from output sales or borrow funds from the financial market to finance capital goods purchases (yielding long-term returns), money can flow to the banks and cover all short-term debts outstanding. This money "reflux" into the banks destroys the money initially created and the circuit comes to a closure. A new circuit can then start as banks issue new loans. ${ }^{11,12}$

Now, if banks create money by fiat and extract from it a value that exceeds the cost of producing it (including to raise and hold fractional reserves to back it up) plus a compensation for providing services relating to its use, then they do receive a rent which as such represents unearned income. Such rent implies a net subtraction of real

\footnotetext{
${ }^{9}$ The literature on the circuit theory of money is too vast for trying to provide here a list of references that would do justice to the many contributors to this brand of non-mainstream monetary economics. One contribution that offers a good illustration of the theory's fundamentals is by Augusto Graziani (2003), one of the theory originators and most inspiring "circuitist." Another excellent reference is Rossi and Rochon (2003).
}

${ }^{10}$ This constraint reflects the fundamental nature of a monetary economy where "money buys goods and goods buy money; but goods do not buy goods" (Clower, 1967). Davidson (1965) well explains (Keynes') "finance motive" for money demand by firms undertaking production, and Borio and Disyatat (2015) clarify the distinction between saving and financing: the former alleviates an economy's resource constraint (if people did not abstain from consuming, they would not release real resources that could be used to invest), while the latter alleviates an economy's financing (cash) constraint (in its absence, no spending could take place, including on such items as financial and real assets, beyond savings made available by output).

${ }^{11}$ Following the illustration by Parguez and Seccareccia (2000), "In the initial phase when banks grant credit, they issue new debts upon themselves which they lend to non-bank agents.... The second phase of the monetary circuit is the period during which non-bank agents spend the money they have borrowed to acquire real resources, which are generally labour and produced commodities. Sellers of labour services or commodities acquire the quantity of money which has been created in the first phase. ... In the third and last stage of the monetary circuit, the initial holders of bank debts seek to recover them in the reflux process out of their receipts generated by their initial expenditure. They can now replenish their deposits and pay back their loans." (p. 104) This highly simplified mechanism can be modified to contemplate the general case where income earners save a share of their incomes; this creates space for financial intermediation, whose role is to facilitate the money reflux process to the banks and to allow circuit closure in condition of stock-flow equilibrium (Bossone 2001a). The model can be further extended to include the case where banks advance money to finance consumption in addition to production (Bossone 2001b).

12 The model assumes for simplicity that the credit issued by commercial banks is used only to finance production. In fact, the model could be easily modified to represent more realistic cases where banks extend credit to other uses such as consumption, financial trading, investment in real estate or the exchange of existing (nonreproducible) assets (Turner, 2016). 
resources from the economy's output and goes to the exclusive benefit of the bank owners. As it relates to money creation, such a rent is a form of seigniorage. ${ }^{13}$

It is now recognized (even by mainstream economists ${ }^{14}$ ) that in a fractional reserves regime commercial banks create the money they lend in the form of newly issued demand deposits. ${ }^{15}$ Commercial banks create their own demand deposit liabilities by crediting borrowers' accounts with the funds loaned; by such act of creation, new liabilities and assets are simultaneously recorded on the bank's balance sheet. These money creation features are indeed unique to banking, in as much as banks only are allowed by regulation to i) both hold customers' demand deposits and issue loans to customers in the form of demand deposits and ii) carry both operations within customer accounts held in their own books. On the other hand, these same features are not shared by pure financial intermediaries, which a) can only intermediate pre-existing funds, and b) can perform lending only by ordering fund transfers across accounts held with third parties (banking institutions). ${ }^{16}$ Thus, while commercial bank lending is not constrained by existing deposits (and, in fact, lending creates new deposits), lending from pure financial intermediaries is constrained by existing savings.

Importantly, however, commercial bank lending is not unconstrained. When extending loans, banks need to avail themselves of the resources required (by payment system rules or central bank regulation) to settle the obligations that are triggered when the loaned deposits are mobilized by customers or when customers demand to withdraw

\footnotetext{
${ }^{13}$ More generally, banks create money not only when they lend but also when they sell deposits. Lending deposits features very close analogies to selling deposits. As banks issue deposits to customers in exchange for money, banks become owners of the money received and acquire the rights to use it as they wish (subject to existing laws and regulations). Even if the banks are constrained in the use of the money - such as, for instance, in the case of regulation prescribing the types of assets to be held - they (not the depositors) are the owners of the purchased assets and they (not the depositors) are the owners of the income generated by the assets purchased.

14 See Bank of England's McLeay et al. (2014a, b), and Jakab and Kumhof (2015).

15 Werner (2014) offers a very detailed reconstruction of the accounting process underpinning commercial bank money creation.

${ }^{16}$ To further clarify: when a nonbank financial intermediary intermediate funds, say, by accepting savings from customers against the issuance of term liabilities and by extending mortgages to homebuyers, the intermediary receives the funds from customers in the form of demand deposits (which it holds in a commercial bank account) and transfers those funds to the homebuyers in the form of demand deposits (drawn from that same account). In such an example of pure financial intermediation, there is no money creation and the funds lent to the homebuyers are the same funds that were originally saved by the intermediary's customers. It should be noted that all fund transfers in the example (i.e., from the customers to the intermediary, and from the intermediary to the homebuyers) take place across accounts held with commercial banks.
} 
cash. The availability of such resources and their cost, as well as the demand for loans from the economy and the credit risk associated with the use and users of such loans, all influence the amount of lending decided by banks. The settlement resources needed by commercial banks consist of:

i. Cash reserves and reserves deposited with the central bank

ii. Reserves from settlement of incoming payments from other banks

iii. Borrowings from the interbank market

iv. Borrowings from the central bank

v. Immediate liquidation of unencumbered assets in the balance sheet, and

vi. New deposits of cash from old and new customers (since new noncash deposits from customers can only consist of deposits transferred from other banks, which fall under item ii.

CHART 1. DETERMINANTS OF COMMERCIAL BANK SEIGNIORAGE

\begin{tabular}{|c|c|c|}
\hline Determining factor & Effects & Impact on seigniorage \\
\hline $\begin{array}{l}\text { Operating scale of each } \\
\text { bank }\end{array}$ & $\begin{array}{l}\text { A higher scale: } \\
\text { - increases the bank's } \\
\text { balance sheet } \\
\text { - increases the share of } \\
\text { payments settled on the } \\
\text { bank's books ("on us") }\end{array}$ & $\begin{array}{l}\text { Seigniorage increases due to } \\
\begin{array}{l}\text { bank's higher profit base } \\
\text { bank's lower optimal } \\
\text { reserves for payment } \\
\text { settlement }\end{array}\end{array}$ \\
\hline $\begin{array}{l}\text { Agents' preference for } \\
\text { using demand deposits as } \\
\text { money }\end{array}$ & $\begin{array}{l}\text { Lowers cost of issuing deposit } \\
\text { liabilities }\end{array}$ & $\begin{array}{l}\text { Seigniorage increases due to } \\
>\text { higher profit margin }\end{array}$ \\
\hline $\begin{array}{l}\text { Market power of each } \\
\text { bank }\end{array}$ & $\begin{array}{l}\text { Stronger market power } \\
\text { increases the loan interest rate } \\
\text { and decreases the deposit } \\
\text { interest rate }\end{array}$ & $\begin{array}{l}\text { Seigniorage increases due to } \\
>\text { higher interest rate } \\
\text { margin }\end{array}$ \\
\hline $\begin{array}{l}\text { Settlement rules and } \\
\text { technologies }\end{array}$ & $\begin{array}{l}\text { Use of deferred net settlement } \\
\text { or adoption of liquidity-saving } \\
\text { mechanisms in real-time gross } \\
\text { settlement decreases banks' } \\
\text { demand for settlement reserves }\end{array}$ & $\begin{array}{l}\text { Seigniorage increases due to } \\
>\text { lower cost of liabilities } \\
\text { management }\end{array}$ \\
\hline
\end{tabular}


Acquiring and holding such resources is costly for banks, and they thus detract from their seigniorage. Yet, four factors allow banks to economize on the cost and use of such resources. The impact of these factors on seigniorage is outlined in Chart 1 and is analytically discussed in Appendices I-III. They include:

a. The economy's desire to hold commercial bank deposits that pay less interest than bonds (Baltensperger, 1997). This is due to the "moneyness" of demand deposits, as supported by the whole complex of institutional, technical and policy solutions that support public trust in their use as money (which includes inter alia payment infrastructures, banking supervision, central bank liquidity support, deposit insurance, etc.). This factor allows banks to save on the cost of liabilities vis-à-vis other types of financial intermediaries.

b. The operating scale at which individual banks operate. In a fractional reserves regime banks hold only a fraction of reserves against their total deposit liabilities. Similarly, the volume of reserves they actually use for settling interbank obligations and for cash withdrawal from customers are only a fraction of the total transactions settled. Economies of scale allow banks to further economize on the use of reserves. They relate to i) the share of total payment transactions that a bank intermediates: the larger the share of incoming payments (and, hence, of settlement reserves received) the bank receives from the others, the less it needs to raise and hold reserves to settle outgoing payments, and ii) the number of depositors: this allows the bank to settle a larger share of payments in its own books ("on us" payments), to expand its sources of reserves through incoming transfers and payment, and to benefit from asynchronous withdrawals of deposits from depositors. ${ }^{17}$ Consolidation generates increasing returns for banks, enabling them to create liabilities (by lending or selling deposits) with decreasing reserve margins needed for coverage. Thus, the larger the deposit base (scale) of a bank, the higher the seigniorage the bank can extract from deposit creation. More broadly, ceteris

\footnotetext{
${ }^{17}$ In the hypothetical case of a cashless economy with a fully consolidated banking system where all agents held accounts with only one bank, all payments and money transfers would be "on us" for the single bank. The bank would need no reserves for settling transactions and would be under no debt obligation towards its customers. It might in fact create all the money the economy would be willing to absorb at a given interest rate, without holding (costly) reserves, and the money would de facto become the accepted instrument to settle debts within the economy.
} 
paribus, the larger the economies of scale a bank exploits in the use of settlement money, the higher its seigniorage power. Economies of scale in the use of reserves combine with scale economies in bank production, which empirical research show to be significant. ${ }^{18}$

c. The market power of each bank. If free entry were allowed into commercial banking, seigniorage would be reduced accordingly, as banks would compete with each other on the liability and asset side of their balance sheet until their extra profits would vanish. In fact, policy regulations restrict the number of bank entries into the market, preserving their financial soundness as well as their franchise. ${ }^{19}$ Commercial banks do extract seigniorage as a consequence of such regulatory restrictions. ${ }^{20}$ All else equal, seigniorage is higher in more consolidated banking systems where banks exercise their quasi-monopolistic power and extract larger rents from higher interest rate margins. ${ }^{21,22}$

d. Payment system settlement rules and technologies. While the operating scale of individual banks, discussed above, affects each bank's optimal demand for reserves at the margin, payment settlement rules and technologies determine the structural need for reserves of the whole system. Payment system rules determine such need via two channels: the settlement modality (typically netting or gross) and the

\footnotetext{
${ }^{18}$ See Anolli et al. (2015) and Wheelock and Wilson (2015), and the ample literature therein referred, which shows that banks (especially large ones) operate under increasing returns to scale in production. Also, as Bossone and Lee (2004) show, value-maximizing financial intermediaries benefit from "systemic scale economies" effects, whereby intermediaries operating in large systems are expected to have lower costs of production, risk absorption, and reputation signaling than intermediaries operating in small systems

${ }^{19}$ Hellman et al. (2000) argue that regulation must ensure the rent-extraction capacity of commercial banks.

${ }^{20}$ The application to "non-sovereign" entities, such as commercial banks, of the concept of "seigniorage" (which typically applies to "sovereign" entities) seems to be justified precisely in light of the power to create money they acquired by (tacit) permission by the public authority.

${ }^{21}$ Also, while public regulations limit market entry, they also usually seek to promote competition within the banking sector and to prevent, where feasible, their domestic banking market from becoming dominated by a single or few entities.

${ }^{22}$ It should be noted, however, that seigniorage is not the same as monopoly (or oligopoly): whereas monopolists (or oligopolists) typically hold exclusive control of a scarce (or even irreproducible) resource, the sovereign exerting seigniorage may create the resource ex nihilo and in principles at will, limited only by the economy's demand for loans at the given interest rate. Appendix III shows analytically the difference between seigniorage from money creation and profit from pure financial intermediation.
} 
technology adopted. As shown in Appendix III, each of two modalities has a drastically different effect on the system's use of reserves, with netting requiring much less reserves than the gross modality (at the cost of higher credit risk from settlement). Similarly, by re-introducing elements of netting into the gross modality, modern technologies (such as liquidity-saving mechanisms) increase the velocity of reserves circulation in payment systems and allow banks to economize on the use of reserves for any given volume and value of payments to be settled. Both factors interact with payment system scale economies,${ }^{23}$ and affect the overall level of seigniorage that commercial banks may extract from the economy.

Since seigniorage is inherent in commercial bank money creation, and since it is a cost for the economy, it is important to evaluate its impact on the macroeconomy.

\section{The ECONOMICS OF COMMERCIAL BANK SEIGNIORAGE}

\section{A. Commercial Bank Money and Output}

In order to evaluate the role of commercial bank money for a macroeconomy, and specifically to capture how bank money creation and the related seigniorage affect aggregate output in a context of rational agents (households, firms, and banks), the following four cases are analyzed in this section: i) a neoclassical economy; ii) an economy with commercial bank money, iii) an economy with pure financial intermediation; and iv) an economy with noncredit based money.

Calling $Y$ the real output produced by these economies, the comparison of these four cases establishes

\section{Proposition 1}

Under ceteris paribus conditions, an economy with bank money creation attains higher levels of output than an economy with pure financial intermediation; however, commercial bank seigniorage detracts from the potential level of output that would otherwise be attainable if seigniorage were socialized (i.e., redistributed to society).

That is,

\footnotetext{
${ }^{23}$ Significant scale economies in payment systems are found by Beijnen and Bolt (2007), and by Humphrey (2009).
} 
$\left.Y_{t}\right|_{\text {pure intermediation }}<\left.Y_{t}\right|_{\text {bank credit money }}<\left.Y_{t}\right|_{\text {noncredi money }}<\left.Y_{t}\right|_{\text {neoclassical }}$

\section{Neoclassical economy}

The first case is the (theoretical) benchmark case of an economy with fully-informed agents who fully trust each other, commit to honoring all future obligations, and do honor their obligations seamlessly when they fall due. In such an economy, exchanges are financed by individual IOUs and no (costly) monetary infrastructure is necessary to support the exchange process. $N$ workers supply labor services to firms, and firms are owned by entrepreneurs who organize production by employing labor and capital $K$ through a given technology. The preferences of households (including workers and entrepreneurs as consumers and savers) are defined over a consumption good $C$ and leisure $1-N$. Using standard notation and functional forms, households maximize the expected present discounted value of utility

(1) $\quad \operatorname{Max} U=E_{t} \beta^{i} \sum_{i=0}^{\infty}\left(\frac{\left(C_{t}\right)^{1-\sigma}}{1-\sigma}-\chi \frac{N_{t+i}^{1-\eta}}{1+\eta}\right)$

s. t.

(2) $\quad \sum_{i=0}^{\infty} P_{t} C_{t} \frac{1}{(1+r)^{t}}=\sum_{i=0}^{\infty} \Omega_{t} \frac{1}{(1+r)^{t}}$

where lifetime consumption $C$ must equal lifetime income $\Omega$ (Eq. (2)). The following first order conditions hold in equilibrium:

(3) $\quad C_{t}^{-\sigma}=\beta E_{t}\left(\frac{\left(1+r_{t}^{S}\right) P_{t+1}}{P_{t}} C_{t+1}^{-\sigma}\right)$

(4) $\quad \frac{\chi N_{t}^{\eta}}{C_{t}^{-\sigma}}=\frac{W_{t}}{P_{t}}$

Real output is produced through a CRS Cobb-Douglas technology $Y_{t}=K_{t}^{\alpha} N_{t}^{\beta}$, $\alpha+\beta=1$, where $A$ is a productivity factor. Firms maximize expected intertemporal profits

$$
\operatorname{Max} \Pi^{E}=E_{t} \delta^{i} \sum_{i=0}^{\infty}\left(Y_{t+i} P_{t+i}-K_{t+i} P_{t+i}^{K}-K_{t+i-1} P_{t+i-1}^{K}-W_{t+i} N_{t+i}\right)
$$




$$
=E_{t} \delta^{i} \sum_{i=0}^{\infty}\left(A K_{t+i}^{\alpha} N_{t+i}^{\beta} P_{t+i}-K_{t+i} P_{t+i}^{K}-K_{t+i-1} P_{t+i-1}^{K}-W_{t+i} N_{t+i}\right)
$$

where $P$ is output price and the price of capital $P^{K}$ is the present value of the stream of future profits net of its original cost

$$
P_{t}^{K}=-P_{0}^{K} K_{0}+\sum_{i=0}^{\infty} \frac{\Pi_{t+i}^{E}}{(1+r)^{t}}
$$

with f. o. c.'s given by

$$
\alpha A K_{t+i}^{-\beta} N_{t+i}^{\beta}=\frac{P_{t+i}^{K}}{P_{t+i}}
$$

$$
\beta A K_{t+i}^{\alpha} N_{t+i}^{\beta}=\frac{W_{t+i}}{P_{t+i}}
$$

Capital owners receive profits from the firms they own and allocate them according to optimal plan (1)-(8).

Equilibrium in the goods market requires $y_{t}=C_{t}+I_{t}$, where, $I_{t}=K_{t}-$ $K_{t-1}=s_{t} Y_{t}$, and $C_{t}=C_{t}^{W}+C_{t}^{E}$, superscripts $W$ and $E$ refer, respectively, to workers and entrepreneurs as households. The aggregate resource constraint thus takes the form $y_{t}=C_{t}+S_{t}$, where $C_{t}=\left(1-s_{t}\right) Y_{t}=c_{t} Y_{t}$, and $S=S_{t}^{W}+S_{t}^{E}$.

Substituting Eqs. (4), (6) and (7) into the production function yields equilibrium output in the neoclassical economy as a function of relative prices:

$$
\left.Y_{t}\right|_{\text {neoclassical }}=\mathcal{A}\left(\frac{W_{t+i}}{P_{t+i}} \frac{c_{t+i}^{-\sigma}}{\chi}\right)^{a}\left(\frac{P_{t+i}^{K}}{P_{t+i}}\right)^{b}
$$

where $\mathcal{A}=\left(\alpha^{\frac{1}{\beta}} A^{\frac{2}{\beta}}\right)^{\frac{\eta}{\eta+\sigma \beta}}, a=-\frac{1}{\eta+\sigma \beta}$, and $b=-\frac{1}{\beta(\eta+\sigma \beta)}$,

where $a=-\frac{1}{\eta+\sigma \beta}<-1$ and, a fortiori, $a=-\frac{1}{\eta+\sigma \beta}<-1$ and $b=-\frac{1}{\eta+\sigma \beta}<-1$, for plausible values of coefficients $\eta, \sigma$, and $\beta$. 


\section{Bank credit money economy}

The third case is a circuit monetary production economy (discussed in Section III.B), where individual IOUs are not accepted in the exchange process due to lack of trust among the agents, and where money is thus necessary to relieve the financing (cash-inadvance) constraint and to make exchange possible in a sequential economy. In order for an instrument to be accepted as money in transactions it must be a liability of reputable third-parties. Banks play such role and issue money in the form of demand deposits by extending loans. They provide the monetary infrastructure to support the exchange process. Deposits are fractionally backed by central bank reserves, which serve as settlement instrument for interbank payments and fund transfers. ${ }^{24}$ Banks raise reserves by offering interest-bearing deposit facilities to customers, by receiving payments, or by borrowing from the interbank market or the central bank. For simplicity, but without loss of generality, we assume that the central bank always accommodates the banks' demand for reserves at policy interest rate $r^{R E S}$. Also, for simplicity, lending does not bear risk and no credit risk premium is paid on loan interest rate $r^{L}$. Finally, regulatory restrictions to entry into the banking market ensure that $r^{L}>r^{D}, r^{R E S}$, where $r^{D}$ is the interest paid on deposits. ${ }^{25}$

For simplicity, the model used here does not explicitly include pure financial intermediation and assumes that the demand for and supply of savings are in balance (reflecting the saving-investment equilibrium condition). In the model, all savings are placed as deposits with banks. ${ }^{26}$

Banks are owned by bankers and maximize profits by supplying all loans demanded by firms at interest rate $r^{L}$.

\footnotetext{
${ }^{24}$ In other words, due to the banks' credibility with the public as trustable agents, people use bank IOUs as money. In turn, the central bank acts as the trusted agent of banks and provides the money used for settling interbank obligations.

${ }^{25}$ Following Borio and Disyatat (2015), the rationale for limiting entry rests on the frictions arising from the agents' inability to commit to honoring bilateral obligations and, therefore, to issue their own IOUs. For this reason, only selected agents - banks - are assumed to be able to make their demand deposit liabilities acceptable as settlement medium.

${ }^{26}$ In a complete circuit model (Bossone, 2001a), with banks and pure (nonbank) intermediaries, and under stock-flow equilibrium conditions, the money used for consumption flows directly back to the firms through the goods market, while the money allocated to savings flows back to the firms indirectly through the financial market. The reflow mechanism allows the circuit to come to a closure where all bank loans are paid off and all investments are funded by savings.
} 


$$
\begin{gathered}
\operatorname{Max} \Pi^{B}=E_{t} \delta^{i} \sum_{i=0}^{\infty}\left[L_{t+i}(1+q) r_{t+i}^{D}+v V D_{t+i}-R E S_{t+i}\left(1+r_{t+i}^{R E S}\right)-\right. \\
\left.D_{t+i-1} r_{t+i-1}^{D}\right] \\
=E_{t} \delta^{i} \sum_{i=0}^{\infty}\left[L_{t+i}\left(q r_{t+i}^{D}+v V-\phi r_{t+i}^{R E S}\right)-D_{t+i-1} r_{t+i-1}^{D}\right] \\
=E_{t} \delta^{i} \sum_{i=0}^{\infty}\left[L_{t+i} r_{t+i}^{L}-D_{t+i-1} r_{t+i-1}^{D}\right]
\end{gathered}
$$

where $r_{t}^{L}=q r_{t}^{D}+v V-\phi r^{R E S}$, and

$$
L=D=W N
$$

$$
\begin{aligned}
& \text { (12) } R E S=\phi D \\
& \text { (13) } r_{t}^{R E S}=\bar{r}^{R E S}
\end{aligned}
$$

where bank revenues in Eq. (9) derive from interest income on loans and from net fee $v$ on money services (e.g., liquidity, payments, accounting management), which applies to deposits $D$ through a money velocity parameter $V .{ }^{27}$ Also, banks: issue deposits by extending loans $L$ to firms that need to advance wage payments $W N$ to workers (Eq. (10)); apply mark-up $q$ to deposit interest rate $r^{D}$ to determine loan interest rate $r^{L}$ (Eq. (11)); hold a fraction $\phi$ of deposits in reserves RES at the central bank (Eq. (12)), which is based on their internal liquidity management policy. Notice that $\bar{r}^{R E S} R E S=\Pi^{C B}$ is the seigniorage extracted by the central bank $C B$, which is assumed to operate costlessly; notice, also, that central bank seigniorage is at the expense of commercial bank profits. Finally, the interest cost of reserves $r_{t}^{R E S}$ is set by the central bank as a policy variable (Eq. (13)), implying that at that interest the central bank fully accommodates the demand of reserves demanded by the banks.

\footnotetext{
${ }^{27}$ This simple representation captures the value added provided by banks ensuring monetary circulation.
} 
Since the profit function is linear, profit maximization is entirely driven by loan demand. Bankers receive profits from the banks they own and, like all other household types (i.e., workers and capital owners), they allocate profits according to optimal plan (1)-(8) and, in addition, the cash-in-advance constraint

$$
P_{t} C_{t}=Y_{t} P_{t}+D_{t-1}\left(1+r_{t-1}^{D}\right)-S_{t}
$$

which requires that, at each date, consumption expenses be financed out of incomes (paid by firms in deposits) and/or out of deposits accumulated in earlier periods, net of current savings.

With borrowing, the firms' profit maximization function becomes

$$
\begin{aligned}
& \operatorname{Max} \Pi^{E}=E_{t} \delta^{i} \sum_{i=0}^{\infty}\left[A K_{t+i}^{\alpha} N_{t+i}^{\beta} P_{t+i}-K_{t+i} P_{t+i}^{K}-K_{t+i-1} P_{t+i-1}^{K}-\right. \\
& \left.W_{t+i} N_{t+i}\left(1+r_{t+i}^{L}\right)\right]
\end{aligned}
$$

and the f. o. c.'s are

$$
\begin{aligned}
& \alpha A K_{t+i}^{-\beta} N_{t+i}^{\beta}=\frac{P_{t+i}^{K}}{P_{t+i}} \\
& \beta A K_{t+i}^{\alpha} N_{t+i}^{\beta}=\frac{W_{t+i}}{P_{t+i}}\left(1+r_{t+i}^{L}\right)
\end{aligned}
$$

Using Eqs. (4), (16), and (17) and substituting them in the production function, equilibrium output of the bank credit economy is given by

$$
\left.Y_{t}\right|_{\text {bank credit money }}=\mathcal{A}\left[\frac{W_{t+i}}{P_{t+i}} \frac{c_{t+i}^{-\sigma}}{\chi}\left(1+r_{t+i}^{L}\right)\right]^{a}\left(\frac{P_{t+i}^{K}}{P_{t+i}}\right)^{b}
$$

Eqs. (16)-(17) are crucial to evaluate the impact of money (and money creation) on aggregate output. Eq. (17) shows that if bank credit money is needed to advance wage payments, firms employ labor up to the point where the marginal return on labor services equals the real wage augmented by the real interest rate charged on bank loans. The impact on aggregate output depends on relative price assumptions. Under fixed real wages, the loan interest rate would increase the cost of labor and cause firms to employ less labor services. Assuming $-b<a<-1$ (see above), this would lead to inequality $\left[\frac{W_{t+i}}{P_{t+i}} \frac{c_{t+i}^{-\sigma}}{\chi}\left(1+r_{t+i}^{L}\right)\right]^{a}<\left(\frac{W_{t+i}}{P_{t+i}} \frac{c_{t+i}^{-\sigma}}{\chi}\right)^{a}$. Alternatively, under fully flexible real 
wages, firms would employ the same amount of labor but lower real wages would increase profits (Eq. (15)) and raise the real value of capital (Eq. (6)), yielding inequality $\left[\left(\frac{P_{t+i}^{K}}{P_{t+i}}\right)^{b} \mid r^{L}>0\right]<\left[\left(\frac{P_{t+i}^{K}}{P_{t+i}}\right)^{b} \mid r^{L}=0\right]$. In both cases,

(18) $\left.Y_{t}\right|_{\text {bank credit money }}<\left.Y_{t}\right|_{\text {neoclassical }}$.

\section{Pure financial intermediation economy}

Suppose the economy is in all respects identical to the one just discussed, except that bank money creation through credit is not allowed and only financial intermediation is admitted. That is, financial intermediaries may not create the money they wish to lend but can only lend the money that is deposited with them. Under such conditions, unlike in the case with banks, money has to pre-exist in the form of savings and savings constrain the demand for labor from firms, thus limiting aggregate output to lower levels than in the economy with banks.

That is, defining $N^{\wedge}$ and $N$ as the constrained and unconstrained levels of equilibrium employment, respectively, such that $N^{\wedge}<N$, aggregate output under pure financial intermediation is given by

$$
\left.Y_{t}\right|_{\text {pure intermediation }}=\mathcal{A}\left[\left(\frac{W_{t+i}}{P_{t+i}} \frac{c_{t+i}^{-\sigma}}{\chi} \mid N^{\wedge}\right)\left(1+r_{t+i}^{L}\right)\right]^{a}\left(\frac{P_{t+i}^{K}}{P_{t+i}}\right)^{b}
$$

where $\left(\frac{W_{t+i}}{P_{t+i}} \frac{c_{t+i}^{-\sigma}}{\chi} \mid N^{\wedge}\right)>\left(\frac{W_{t+i}}{P_{t+i}} \frac{c_{t+i}^{-\sigma}}{\chi} \mid N\right)$ since, all else equal, the marginal productivity of labor is higher at lower levels of employment and is reflected in higher real wages. Thus,

$$
\left.Y_{t}\right|_{\text {pure intermediation }}<\left.Y_{t}\right|_{\text {bank credit money }} .
$$

\section{Noncredit money economy}

An example of an economy with noncredit money was developed by Bossone and Sarr (cit.). As in the credit money economy discussed above, agents do not fully trust each other, and money is required to relieve the financing (cash-in-advance) constraint of agents engaging in economic activities. A (costly) infrastructure is thus necessary in this case, too, to make the exchange process possible. The only critical difference is 
that in a noncredit money economy money creation is separated from the extension of credit, and money is issued and distributed to agents by specialized payment service providers, called deposit creating institutions (DCIs), which issue deposits on a nonlending basis and charge fees on money services only. All relationships are therefore the same as in a bank credit money economy, with the exception of the DCI profit function, which becomes

$$
\begin{gathered}
\Pi^{D C I}=E_{t} \delta^{i} \sum_{i=0}^{\infty}\left[D_{t+i}\left(v V-\phi r_{t+i}^{R E S}\right)-D_{t+i-1} r_{t+i-1}^{D}\right] \\
=E_{t} \delta^{i} \sum_{i=0}^{\infty}\left[D_{t+i} r_{t+i}^{D C I}-D_{t+i-1} r_{t+i-1}^{D}\right] .
\end{gathered}
$$

The economy's output is therefore

$$
\left.Y_{t}\right|_{\text {noncredit money }}=\mathcal{A}\left[\frac{W_{t+i}}{P_{t+i}} \frac{c_{t+i}^{-\sigma}}{\chi}\left(1+r_{t+i}^{D C I}\right)\right]^{a}\left(\frac{P_{t+i}^{K}}{P_{t+i}}\right)^{b}
$$

where $r_{t+i}^{D C I}<r_{t+i}^{L}$. The lower cost of money would lead to larger employment, lower marginal productivity of labor and lower real wages. Assuming $b<a<-1$ (see above), this would lead to inequality:

$$
\left.Y_{t}\right|_{\text {noncredit money }}>\left.Y_{t}\right|_{\text {bank }} \text { credit money }
$$

Together, inequalities (18), (19), and (21) prove Proposition 1 above, whereby $\left.Y_{t}\right|_{\text {pure intermediation }}<\left.Y_{t}\right|_{\text {bank credit money }}<\left.Y_{t}\right|_{\text {noncredit money }}<\left.Y_{t}\right|_{\text {neoclassical }}$

The inequality suggests that:

- Bank credit money allows an economy to achieve higher levels of aggregate output than pure financial intermediation.

- The cost of issuing money affects aggregate output: if money issuers extract seigniorage from the economy, and no mechanism is provided to re-inject the extracted resources into the economy, aggregate output will be correspondingly lower. 
- Economies where money would be issued on a non-lending basis and through decentralized institutions (like the DCIs) would remove (socialize) seigniorage and achieve higher levels of aggregate output.

- Finally, to the extent that the agents do not fully trust each other, money is necessary and requires costly supporting infrastructures to make the exchange process possible. As a result, while representing a useful benchmark, the neoclassical economy case (which assumes full trust) remains unrealizable in practice.

Even deeper differences lie underneath bank seigniorage than those just discussed. They require looking at the distributional structure of the economy, the subject of the next section.

\section{Commercial Bank Seigniorage ANd Resource Distribution}

If commercial bank seigniorage, as a rent, is a form of unearned income and, therefore represents an extraction of net real resources from the economy, how does it affect resource distribution across the economy?

Obviously, the overall impact of seigniorage must be a function of how much of it commercial banks extract from a given system during a given time period - an assessment of its impact can only be country specific and subject to estimation procedures. This article does not attempt to do so; rather, its purpose is to understand the channels through which commercial bank seigniorage may affect the economy's resource distribution process.

A simple structuralist model with circuit financing and reflow features is used to this purpose, in this section and the next. ${ }^{28} \mathrm{~A}$ three-sector economy is assumed, which involves banks issuing the economy's money, firms producing consumption and capital goods, and workers employed by the firms and allocating resources intertemporally.

\footnotetext{
${ }^{28}$ For a comprehensive treatment of structuralist economics, see Taylor (2004).
} 
At the economy's competitive equilibrium output $Y^{*}$ (with no extra-rents or seigniorage) derived as above, each sector receives as income a share of the aggregate output that equals the sector's value added:

$$
Y^{*}=\frac{W N}{P}+\frac{\Pi^{E} K}{P}+\frac{\Pi^{B} L}{P}
$$

where central bank seigniorage is ignored, $\Pi^{E}$ and $\Pi^{B}$ are the unit profit rates for firms and banks, respectively, and $\Pi^{B}$ is obtained by suppressing the term in $r_{t}^{L}$ (commercial bank seigniorage) from Eq. (14) to include only banks' actual value added corresponding to the provision of money services. If one (or more) of the sectors extract a non-zero rent from the economy, however, output must be redistributed across sectors, otherwise it would not be enough to support the rents in addition to the original sector income compensations. Calling $r$ the seigniorage extracted by the banks extending loans to firms for wage advances, Eq. (22) becomes inequality

$$
Y^{*}<\frac{W N}{P}(1+r)+\frac{\Pi^{E} K}{P}+\frac{\Pi^{B} L}{P}
$$

In order to re-establish equilibrium, firms must then set prices so that

$$
\begin{aligned}
Y^{*} & =\left[\frac{W N}{P}(1+r)+\frac{\Pi^{K} K}{P}+\frac{\Pi^{B} L}{P}\right] \frac{1}{\left(1+p^{*}\right)} \\
& =\frac{W N}{P^{*}}(1+r)+\frac{\Pi^{K} K}{P^{*}}+\frac{\Pi^{B} L}{P^{*}}
\end{aligned}
$$

where $P^{*}=\left(1+p^{*}\right) P$ is the equilibrium price level when firms borrow from banks, and $p^{*}$ (here defined as the "optimal" rate of inflation) is the implicit rate of price adjustment needed to solve for the new equilibrium under Eq. (24). In other words: firms set prices optimally, that is, high enough to extract from the economy the real resources needed to pay for production factors and to repay their bank loans at circuit closure, and low enough to minimize the impact of higher prices on consumption demand and labor supply.

Through money creation banks do not add value to the economy's real output besides $v V D_{t}$, that is, the provision of money services as the public good needed to facilitate the economy's exchange process. Yet they charge on their loans an interest rate $r$ that is not the reward of any acts of thrift from savers or the compensation for 
agents temporarily separating from liquidity, since the money that is loaned is not preexisting and is created by the banks ex nihilo at a cost that is lower than $r$ (see Appendix I). Thus, banks draw from the economy a share of output they have not contributed to produce. This necessarily causes an erosion of the real value of money through an increase in the general price level, which serves as a rationing device of the given output across the economy against excess claims on it. The distributional implications of resource rationing will be discussed further below; here, it suffices to notice that with any (suboptimal) price level $P^{\prime} \neq P^{*}$, or if $P^{*} \operatorname{did}$ not exist, then

$$
Y^{*}<\frac{W N}{P^{\prime}}(1+r)+\frac{\Pi^{E} K}{P^{\prime}}+\frac{\Pi^{B} L}{P^{\prime}}
$$

and the firms would either have to re-finance their original loans by raising new bank debt $\Delta D$

$$
Y^{*}+\Delta D=\frac{W N}{P^{\prime}}(1+r)+\frac{\Pi^{E} K}{P^{\prime}}+\frac{\Pi^{B} L}{P^{\prime}}
$$

or they would be forced into default. Assuming $P^{*}$ exists and dividing the terms in Eq. (24) by the number of workers yields

$$
\frac{Y}{N}=\frac{W}{P^{*}}(1+r)+\frac{\Pi^{E} K}{P^{*} N}+\frac{\Pi^{B} L}{P^{*} N}
$$

Using logarithmic transformations, applying Taylor's expansion to derive the equality $\ln (1+r)=r$ under realistic conditions, ${ }^{29}$ and rearranging terms in Eq. (27) lead to

$$
r=\lambda-\left[\left(w-p^{*}\right)+\left(\pi^{E}-p^{*}\right)+(k-n)\right]
$$

where $\lambda \equiv y-n$ is labor productivity growth, $\pi^{E}$ is the rate of change of firms' profit, and $p^{*}$ is the optimal rate of inflation (in the sense defined above), and where it is assumed that banks are always in a position to protect the real value of their (normal) profits (that is, $\pi^{B}=p^{*}$ ) and that they accommodate labor growth (that is, $l=n$ ).

\footnotetext{
29 From Taylor's expansion, $\ln (1+r)=r-\frac{r^{2}}{2}+\frac{r^{3}}{3}-\frac{r^{4}}{4}+\frac{r^{5}}{5}-\cdots=\sum_{n=1}^{\infty}(-1)^{n+1} \frac{r^{n}}{n}, \forall r \in$ $(-1,1]$, and $\lim _{n \rightarrow \infty}\left(R_{n}\right)=-\frac{r}{2}+\frac{r^{3}}{3}-\frac{r^{4}}{4}+\frac{r^{5}}{5}-\cdots=\frac{(-1)^{n}}{(1+\xi)^{n+1}} \frac{(r)^{n+1}}{(n+1) !}=0, \forall \xi \in(0, i)$, and $\forall r \in(-1,1]$. Thus, $\ln (1+r)=r$.
} 
Eq. (27) determines the net real interest rate as the share of productivity growth that is expropriated by the banking sector from workers and firms. Its algebra does not derive results that are not already implicit in the model's assumptions; rather, it makes explicit the growth accounting relationships between the economic sectors considered. In particular, Eq. (28) highlights:

- The positive relationship between seigniorage and labor productivity growth

- The positive relationship between seigniorage and inflation

- The negative relationship between seigniorage and the rate of change of wages and capital goods prices, respectively, and

- The negative relationship between seigniorage and capital endowment per worker.

These relationships should be understood in the context of the distributional dynamics characterizing any given economy. They indicate how the space for commercial bank seigniorage changes with changes in the economic variables included in the structuralist model, and vice versa, relative to the structure of the particular economy under consideration. The following analysis will further clarify the nature of the inter-sectoral relationships.

\section{ECONOMics AND ECONOMic POLICY IMPLications}

Eq. (28) identifies the constituent elements of commercial bank seigniorage. It suggests that such form of seigniorage depends on the political economy context in which banks and the other economic agents act, including their power (as groups or classes) to affect the economy's resource distribution process. For instance, all else equal, the less open and competitive the market environment where banks operate, the stronger their power to set interest rates and, therefore, the higher their capacity to extract rents from the economy and the level of labor productivity growth required for firms to be able to repay their bank debt. Similarly, the weaker the wage negotiating power of workers, and the lower the firms' capacity to protect the value of capital from inflation, the higher the rents going to the banks for any given level of labor productivity growth. Most notable, in point of political economy considerations, is the equation's indication of a 
strongly negative relationship between the seigniorage power of banks and the share of national output going to workers (through real wages).

\section{A. Three Relevant Cases}

Three cases are of interest and require consideration:

a) The case where firms protect the value of capital

b) The neoclassical ("golden rule") case where the marginal productivity of labor equals the real wage, and

c) The case where nominal wage growth lags inflation.

\section{Case A: Protecting the value of capital}

In this case, firms protect the value of their capital by setting $\pi^{E} \geq p^{*}$, that is, they set the rate of change of profit to be at least equal the optimal rate of inflation. For $i>0$, then, and assuming stationarity of the capital endowment per worker, $k-n=0$, it must follow that $\lambda \geq\left(w-p^{*}\right)$, which either requires firms to engineer an increase in labor productivity for given real wage dynamics or to compress real wage growth through internal devaluation and/or higher inflation: protecting the value of capital at positive interest rates on loans implies that a positive surplus must be extracted from the workers by the firms for them to be able to repay their loans to the banks. Call labor appropriation the net resources corresponding to the positive difference $\lambda-\left(w-p^{*}\right)$, in Eq. (25), which accrues to the banking sector at circuit closure through rent extraction (seigniorage) through lending.

\section{Case B: The neoclassical "golden rule"}

In this case, the economy follows the neoclassical rule whereby labor productivity and real wages grow at the same rate, $\lambda=w-p^{*}>0$, bank seigniorage $(r>0)$ requires that value be extracted from the firms' capital, $p^{*}>p^{K}$. This implies that firms' capital progressively shifts into the hands of the banks. After workers are rewarded for productivity increases through real wage adjustments, call capital expropriation the net resources $\left(\pi^{E}-p^{*}\right)+(k-n)$ accruing to the banking sector at circuit closure through rent extraction (seigniorage). Notice that, for any given price-wage dynamics, 
capital expropriation grows with the capital-to-labor ratio: bank seigniorage disincentivizes capital accumulation.

\section{Case C: Wages lag inflation}

Finally, this the case when $w<p^{*}$, that is, when real wages decline. This case would materialize when nominal wages lag price inflation. According to Eq. (28), bank seigniorage $(r>0)$ requires that $\lambda-\left[\left(w-p^{*}\right)+\left(\pi^{E}-p^{*}\right)+(k-n)\right]>0$. Assuming stationarity (that is, $\lambda=0$ and $k-n=0$ ), the condition can be re-written as $\left(\pi^{E}-p^{*}\right)<\left(p^{*}-w\right)$, that is, both banks and firms may gain at the expense of workers since seigniorage is positive and firms protect the value of capital by raising their profit rate above inflation, provided real profits grow less than the difference between inflation and wages. Under such condition, both banks and firms would further gain from increases in labor productivity and capital endowment per worker.

In all cases, the very existence of commercial bank seigniorage affects resource distribution between firms and workers. Moreover, given the sanctity of debt, whereby bank loans would always have to be paid off, seigniorage inevitably generates a tension between the two classes of agents and determines a zero-sum game type of situation where one class may gain only at the expense of the other, and where firms' inability to protect the value of their capital would eventually resolve in their equity being repossessed by banks.

\section{B. Considerations}

From the results in this section and the previous, the model shows that: i) commercial bank seigniorage determines a higher equilibrium general price level; ii) an increase in commercial bank seigniorage raises inflation with deflationary consequences on the purchasing power of agents in the other sectors of the economy (i.e., firms and/or workers), and iii) commercial banks play a key role in determining resource distribution within the economy and across its sectors.

In the model, price increases are the firms' response to commercial bank seigniorage: such responses are the device though which firms seek to alter the distribution of real output in the economy so that they can pay for the costs of production factors and service their debts with banks. Such debts do not derive from 
the financial intermediation of pre-existing money from savers to investors. ${ }^{30}$ They originate from the claims on real resources created (ex nihilo) by the banking system through lending: they correspond to net positive rent transfers from the economy to the banks.

Also, from Eq. (26) it follows that if firms are unable to recover the resources needed to fulfill their obligations, they have to resort to new bank lending. To the extent that banks are willing to evergreening existing debts, new debts can accumulate over time until the firms either succeed in raising the necessary resources to keep current with their obligations or they are forced to default on their obligations (and their capital is then seized by creditor banks).

Commercial bank seigniorage diverts real resources from the economy to the banking sector and generates distributional tensions between capital and labor.

\section{Economic Policy Implications}

The results thus obtained bear implications for macroeconomic policy. Here are just some preliminary considerations, which could be extended through further research on the issue of commercial bank seigniorage.

\section{Monetary policy}

The model above abstracts from the cost to commercial banks from having to attract and hold central banks reserves (for reserves requirements and/or for payment settlement purposes) or from having to pledge securities to be able to access central bank reserves in case of liquidity needs. Both types of cost would in fact reduce commercial bank seigniorage. Extending the model to include commercial banks' demand for both central bank reserves and collateral creates space for monetary policy. The central bank's policy interest rate(s) would be a cost to commercial banks and would influence their decisions on loan interest charges.

Under a Taylor monetary policy rule, the central bank would increase the policy interest rates if inflation were above target. To a point, an increase in the policy interest

\footnotetext{
${ }^{30}$ As noted above, in circuit models, production (of both consumption and capital goods) is financed with bank money, whereas financial intermediation allocates savings and fund investing firms that plan to purchase the capital goods produced.
} 
rates would, in the model above, induce commercial banks to raise their rates and firms to increase prices accordingly - a result that is analyzed by the monetary policy "cost channel" literature and is in line with Neo-Fisherian predictions. ${ }^{31}$ However, as structuralist analysis indicates, if nominal wages and/or firm profits did not keep pace with inflation, there would be a critical threshold beyond which further price adjustments would no longer be sustainable either because additional value extraction from labor and/or capital would not be accepted from workers and firms or because compression of real remunerations of labor and capital would cause output to drop. Price dynamics would be brought under control but, as long as commercial bank seigniorage kept increasing, further price adjustments would be inhibited eventually causing firms to default on their debt obligations.

In spite of central bank action on policy rates, the outcome just described could be prevented if commercial banks were willing to renew old loans and to extend new ones to firms, and if firms were willing to: borrow from banks (possibly at higher interest rates); increase sale prices; and accommodate worker demands for higher nominal wages. In this case, higher policy rates would lead to growing money creation and increasing lending rates as well as to accelerating price and wage inflation rates, possibly setting off spiraling interest-price-wage dynamics. Effective monetary restraint would require the central bank to abandon the interest rate policy in favor of quantity targeting, and to ration the supply of reserves to commercial banks, with the consequences of disruptive debt repayments and the payments activity across the economy.

\section{Fiscal policy}

Unless there is a mechanism that automatically forces the re-injection into the economy of the seigniorage extracted from it, commercial bank seigniorage (under antiinflationary monetary policy) introduces a structural contractionary tendency in the real economy by depressing real profits and/or wages. There is therefore a potential role for fiscal policy to play by having the government run a budget deficit that fill in the gap and compensate for the resource-drainage effect.

\footnotetext{
${ }^{31}$ See references in Section II.A.
} 
Importantly, given the structural nature of the resource drainage caused by seigniorage, the deficit needed to offset this effect would have to become a permanent feature of the economy, not just a temporary counter-cyclical measure, and would need to be calibrated to the size of seigniorage: the higher the interest rate (i.e., the larger the commercial bank seigniorage), the larger would have to be the fiscal deficit required to offset the resource drainage. This conclusion runs against the orthodox, over-the-cycle balanced-budget fiscal policy tenet. In the longer run, depending on the magnitude of the resource- drainage effect, the permanent fiscal deficit component would raise sustainability issues of public sector liabilities.

\section{CONCLUding REMARKS}

A few considerations before concluding this work. First, a counterargument to commercial bank seigniorage is that the remuneration that commercial banks earn on their lending activity is not seigniorage but rather a share in the newly created output corresponding to the resource allocation services that banks provide to society by applying their specialized screening and monitoring technologies to lending. ${ }^{32}$ In response to this counterargument, while these specialized services do represent a contribution to output, and their provision involves costs, they are not inherently associated with the banks' money creation process.

To make this point more precisely: as Appendix I shows, a financial intermediary may extract value in excess of its costs (seigniorage) if it has the privilege of issuing interest-bearing loans through deposit creation, and if it operates at a scale that allows it to economize on the cost of managing its liabilities.

One must realize, however, that (as noted already in footnote 5) money creation through lending by decentralized banks provides contemporary economies with degrees of money supply flexibility that would not be available under centralized architectures. Narrow banking solutions, for example, would most likely increase the cost of lending to the economy (Bossone, 2001c) and it would possibly make resource allocation less efficient by centralizing the money supply process under full state control.

\footnotetext{
${ }^{32}$ I owe this comment to my friend and colleague Abdou Sarr.
} 
Second, rents from commercial bank seigniorage are ultimately transferred to bank shareholders as dividends, much the same as central bank profits are (partly) given back to taxpayers. ${ }^{33}$ Yet, aside from the fact that much of central bank seigniorage lies hidden in central bank financial statements (Bossone et al., 2018), there is a substantial difference between the two cases. In the central bank case, net resources are extracted from the economy and (partly) returned to the economy through the fiscal budget. On the other hand, in the case of commercial banks, resources are extracted from the economy and appropriated by the bank owners. The extraction and privatization of these rents may cause the structural resource-drainage effect discussed above and generate distributional tensions between capital and labor.

In conclusion, this article has focused on the seigniorage extracted by commercial banks from the economy as they create money through lending. Its purpose was to shed light on the impact that commercial bank seigniorage may have on the macroeconomy both in terms of aggregate output and resource distribution - an issue that has not yet received attention from economic theory. The article has also identified the conditions under which commercial banks extract seigniorage, clarified the relationship between seigniorage from commercial bank money creation and profits from pure financial intermediation, and shown how commercial bank seigniorage changes under different payment settlement rules.

Commercial bank seigniorage may have relevant consequences and implications, which call for further studies and empirical research. It should be transparently (and correctly) accounted for, and its distribution and use should be the subject of public policy discussion for purposes of social equity and economic efficiency.

\footnotetext{
${ }^{33}$ I owe this observation to Nick Rowe.
} 


\section{REFERENCES}

Anolli, M., E. Beccalli, and G. Borello (2015), “Are European banks too big? Evidence on economies of scale, “Journal of Banking \& Finance, 58, pp. 232-246.

Arby, M. F. (2006), "Seigniorage Earnings of Commercial Banks and State Bank of Pakistan,” Munich Personal RePEc Archive.

Baltensperger, E., and T. J. Jordan (1997), "Seigniorage, Banking, and the Optimal Quantity of Money,” Journal of Banking \& Finance 21 (6): 781-96.

Barth, M.J.III., and V. A. Ramey (2001), “The cost channel of monetary transmission,” in NBER Macroeconomic Annual 2001. MIT Press, Cambridge, MA, 199-239.

Bjerg, O., D. McCann, L. Macfarlane, R. H. Nielsen, and J. Ryan-Collins (2017), "Seigniorage in the 21st Century: A study of the profits from money creation in the United Kingdom and Denmark," CBS Working Paper, January.

Beijnen, C., and W. Bolt (2007), "Size matters: economies of scale in European payments processing," DNB Working Paper, No. 155, November.

Borio, C., and P. Disyatat (2015), "Capital flows and the current account: Taking financing (more) seriously," BIS Working Papers No 525, Bank for International Settlement, October.

Bossone, B. (2000), "What Makes Banks Special? A study on banking, finance, and economic development," Policy Research Working Paper WPS2408, The World, Bank.

Bossone, B (2001a), "Circuit theory of banking and finance," Journal of Banking and Finance, Vol. 25, Issue 5, vol. 25, issue 5, 857-890.

Bossone, B. (2001b), "Do banks have a future? A study on banking and finance as we move into the Third Millennium," Journal of Banking and Finance, Vol. 25, Issue 12, 2239-2276.

Bossone, B. (2001c) “Should banks be narrowed?”, IMF Working Paper WP/01/159, International Monetary Fund. 
Bossone, B (2017), “Circuit theory of banking and finance," reprinted in L. P. Rochon and S. Rossi (eds.), Post-Keynesian Economics, Vol II, Money, Credit and Production, Part III, The Theory of the Monetary Circuit, Elgar, Edward Elgar Publishing.

Bossone, B., M. Costa, A. Cuccia, and G. Valenza (2018), “The 'Accounting View' of Money, forthcoming.

Bossone, B., and J. K. Lee (2004), "In Finance, Size Matters," IMF Staff Papers, Volume 51, Number 1, April.

Bossone, B, and A. Sarr, (2002), “A new financial system for poverty reduction and growth," IMF Working Paper, WP/02/178.

Bossone, B, and A. Sarr (2003), “Thinking the economy as a circuit”, in S. Rossi and L. P. Rochon (ed. by) Modern Theories of Money. The Nature and Role of Money in Capitalist Economies, Edgar, Edward Publishing, Inc.

Buiter, W. H. (2007), “Seigniorage,” Discussion Paper, Economics, No. 2007-8, 1 March.

Bullard, J. (2015), "Neo-Fisherianism," Presentation at the University of Oregon's conference, Expectations in Dynamic Macroeconomic Models, Eugene, Oregon, 13 August.

Cardoso, E. (2003), “Seignorage, Reserve Requirements, and Spreads in Brazil,” in P. Honohan (ed.), "Taxation of Financial Intermediation: Theory and Practice for Emerging Economies," a co-publication of the World Bank and Oxford University Press, 241-267.

Clower, R (1967). "Foundations of monetary theory," in R. Clower (ed.), Monetary Theory, Harmondsworth, Penguin Books.

Christiano, L. J., M. Eichenbaum, and C. L. Evans (2005), "Nominal Rigidities and the Dynamic Effects of a Shock to Monetary Policy," Journal of Political Economy, University of Chicago Press, vol. 113(1), 1-45, February.

Cochrane, J. (2016), “Do Higher Interest Rates Raise or Lower Inflation?” mimeo (available at http://faculty.chicagobooth.edu/john.cochrane/research/papers/fisher.pdf) 
Davidson, P. (1965), “Keynes's Finance Motive,” Oxford Economic Papers, New Series, Vol. 17, No. 1, March, pp. 47-65.

Gaiotti, E., and A. Secchi (2006), "Is There a Cost Channel of Monetary Policy Transmission? An Investigation into the Pricing Behavior of 2,000 Firms," Journal of Money, Credit and Banking, Vol. 38, No. 8, 2013-2037, December.

Graziani, A. (2003), "The Monetary Theory of Production,” Cambridge University Press, Cambridge UK.

Hellmann, T. F., K. C. Murdock, and J. E. Stiglitz (2000), "Liberalization, Moral Hazard in Banking, and Prudential Regulation: Are Capital Requirements Enough?," American Economic Review, Vol. 90, No. 1, March, 147-165.

Humphrey, D. B. (2009), Retail Payments: Integration and Innovation Payment Scale Economies, Competition, and Pricing, ECB Working Paper Series, No. 1136, December.

Jakab, Z., and M. Kumhof (2015), "Banks are not intermediaries of loanable fundsand why this matters," Working Paper No. 529, Bank of England, May.

Macfarlane, L., Ryan-Collins, J., Bjerg, O., Nielsen, R., and McCann, D. (2017), "Making Money from Making Money. Seigniorage in the Modern Economy," New Economics Foundation, Copenhagen Business School.

McLeay, M., Radia, A. and Thomas, R. (2014a), "Money in the Modern Economy: An Introduction,” Bank of England Quarterly Bulletin, 54(1), 4-13.

McLeay, M., Radia, A. and Thomas, R. (2014b), "Money Creation in the Modern Economy," Bank of England Quarterly Bulletin, 54(1), 14-27.

Moore, B. (1979), “The Endogenous Money Stock," Journal of Post Keynesian Economics, 2(1), 49-70.

Moore, B. (1983), "Unpacking the Post Keynesian Black Box: Bank Lending and the Money Supply,” Journal of Post Keynesian Economics, 5(4), 537-556. 
Ravenna, F., and C. E. Walsh (2006), "Optimal monetary policy with the cost channel," Journal of Monetary Economics, Vol. 53, Issue 2, March, 199-216.

Realfonzo, R. (2012), “Circuit Theory,” in J. E. King, The Elgar Companion to Post Keynesian Economics, Edward Elgar, 87-92.

Rossi, S, and L. P. Rochon (ed. by) (2003) Modern Theories of Money. The Nature and Role of Money in Capitalist Economies, Edgar, Edward Publishing, Inc.

Schumpeter, J. A. (1934), The Theory of Economic Development. An Inquiry into Profits, Capital, Credit, Interest, and the Business Cycle, Cambridge, Massachusetts: Harvard University Press.

Soldatos, G. T., and E. Varelas (2015), “On the Quantity Theory of Money, Credit, and Seigniorage," The International Journal of Business and Finance Research, Vol. 9 (5), 93-102.

Taylor, L. (2004) "Reconstructing Macroeconomics: Structuralist Proposals and Critiques of the Mainstream," Harvard University Press, Cambridge, Mass., US.

Turner, A. (2016), "Between Debt and the Devil," Princeton University Press.

Werner, R. A. (2014), "How do banks create money, and why can other firms not do the same? An explanation for the coexistence of lending and deposit-taking," International Review of Financial Analysis, 36, 71-77.

Wheelock, D. C., and P. W. Wilson (2015), "The Evolution of Scale Economies in U.S. Banking," Economic Research, Federal reserve Bank of Saint Louis, Working Paper 2015-021C.

Williamson, S. D., (2016), "Neo-Fisherism: A Radical Idea, or the Most Obvious Solution to the Low-Inflation Problem?", Regional Economist, Federal Reserve Bank of Saint Louis, July. 


\section{APPENDiX I. CONDITIONS FOR COMMERCIAL BANK SEIGNIORAGE}

This appendix shows the conditions under which commercial banks extract seigniorage from the economy through money creation. Bank B operates as a profit-maximizing firm in a fractional reserves regime. It is authorized both to offer its customers demand deposit $\left(D D_{B}\right)$ accounts earning interest $i_{D D}$ and to lend money by crediting customer accounts with funds $L_{B}$ at interest $i_{L}$. For simplicity, the bank faces no costs other than deposit remuneration and the cost of raising central bank reserves RES. Bank B's cost structure, thus, is given by $\left[\left(1-\mu_{B}\right) i_{D D}+\mu_{B} c_{R E S}\right] D D_{B}$, where $\mu_{B}=\frac{R E S_{B}}{D D_{B}}$, with $\mu_{B}<1$, and where $c_{R E S}$ is the unit cost of accessing reserves and is a policy variable determined by the central bank. This is the cost of raising and holding reserves $R E S$ as a fraction of demand deposit liabilities and includes both the remuneration of bank B's demand deposit liabilities and the cost of accessing reserves through alternative sources. ${ }^{34}$ At $c_{R E S}$, the central bank supplies all the reserves that banks demand.

Bank B operates at scale $\sigma_{B}=\frac{D D_{B}}{D D}$, defined as the ratio of the bank's demand deposit liabilities over total demand deposits outstanding in the system, DD. Scale effects are such that at zerodimensional scale, $\sigma_{B}=0$, bank $\mathrm{B}$ is of atomistic size, it operates in a perfectly competitive environment and enjoys no economies of scale in liabilities management, whereas at maximum scale, $\sigma_{B}=1$, bank $\mathrm{B}$ is a monopolist and enjoys the largest economies of scale in liabilities management possible. One may therefore posit:

$$
\text { 1) } i_{L}=i_{L}\left(\sigma_{B}\right)
$$

with derivative $\frac{\partial i_{L}}{\partial \sigma_{B}}>0$ and $i_{L}=i_{L}^{*}$ for $\sigma_{B}=0$, where $i_{B}^{*}$ is the equilibrium loan interest rate under perfect competition,

$$
\text { 2) } i_{D D}=i_{D D}\left(\sigma_{B}\right)
$$

with derivative $\frac{\partial i_{D D}}{\partial \sigma_{B}}<0$ and $i_{D D}=i_{D D}^{*}$ for $\sigma_{B}=0$, where $i_{D D}^{*}$ is the equilibrium deposit interest rate under perfect competition, and

\footnotetext{
${ }^{34}$ As noted earlier in the text, such reserves originate from: i) cash reserves and reserves deposited with the central bank, ii) reserves from settlement of incoming payments from other banks, iii) borrowings from the interbank market; iv) borrowings from the central bank; v) immediate liquidation of unencumbered assets in the balance sheet, and vi) new deposits of cash from old and new customers (since new noncash deposits from customers can only consist of deposits transferred from other banks, which fall under item ii).
} 


\section{3) $\mu_{B}=\mu\left(\sigma_{B}\right)$,}

with derivative $\mu^{\prime}>0$ and $\left\{\begin{array}{l}\lim _{\sigma \rightarrow 0} \mu_{B}=1 \\ \lim _{\sigma \rightarrow 1} \mu_{B}=0\end{array}\right.$.

Under such conditions, at zero-dimensional scale $\left(\sigma_{B}=0\right)$ bank B maximizes its profits by expanding lending up to the point where $i_{B}=i_{D D}+\mu c_{R E S}$, so that

$$
\begin{aligned}
& \left.\operatorname{Max} \Pi_{B}\right|_{\sigma_{B}=0}=i_{L} L_{B}-\left[\left(1-\mu_{B}\right) i_{D D}+\mu_{B} c_{R E S}\right] D D_{B} \\
& =i_{L}^{*} L_{B}^{*}-i_{D D}^{*} D D_{B}^{*}=\left(i_{L}^{*}-i_{D D}^{*}\right) D D_{B}^{*} \equiv \text { normal profit }
\end{aligned}
$$

(since $L_{B}^{*}=D D_{B}^{*}$ ), implying that bank B's extra profit is zero and the bank extracts no seigniorage from the economy.

On the other hand, as the scale of bank B's operation increases, the bank i) takes on higher quasi-monopolistic power and ii) enjoys larger scale economies; as a result, its profit grows above normal, its seigniorage is positive and increases with scale:

$$
\left.\operatorname{Max} \Pi_{B}\right|_{\sigma_{B}=1}>\left.\operatorname{Max} \Pi_{B}\right|_{1>\sigma_{B}>0}>\left.\operatorname{Max} \Pi_{B}\right|_{\sigma_{B}=0} .
$$




\section{ApPendix II. SEIGNiorage from Money Creation ANd Profit From PuRe FINANCIAL INTERMEDIATION}

This appendix clarifies the relationship between seigniorage from commercial bank money creation and profits from pure financial intermediation.

Take two financial intermediaries, bank B and pure intermediary I. Bank B is the same as in Appendix I. Pure intermediary I is authorized to offer its customers (non-demand) term deposit $\left(T D_{I}\right)$ accounts bearing interest $i_{T D}$ and to lend funds $L_{I}$ at interest $i_{I}$. Both intermediaries operate in identical quasi-monopolistic market environments and at the same efficiency scale, $1>\sigma_{B}=\sigma_{I}>0$.

For purposes of comparison, the following assumptions also apply. The two entities feature identical administration and operation cost structures (including, inter alia, such items as the costs for screening, selecting, and monitoring borrowers, and those to enforce contract terms), which for simplicity are set to zero. They face the same credit risk and charge the same interest rate on loans $\left(i_{B}=i_{I}\right)$.

Pure intermediary I must attract TD before lending them to borrowers, and it maximizes profits $\Pi_{I}$ :

$$
\left.\Pi_{I}\right|_{1>\sigma_{I}>0}=i_{I} L_{I}-i_{T D} T D>0
$$

where $i_{I}>i_{T D}$ due to I's quasi-monopolistic power in its market. Owing to the linearity of $\Pi_{I}$, intermediary I supplies all loans that borrowers are willing to absorb at the given interest rate.

Bank B behaves as in Appendix I, and maximizes

$$
\left.\Pi_{B}\right|_{1>\sigma_{B}>0}=i_{L} L_{B}-\left[\left(1-\mu_{B}\right) i_{D D}+\mu_{B} c_{R E S}\right] D D_{B}>0
$$

where $c_{R S}$ is the unit cost of settlement reserves RES, and $i_{L}>\left[\left(1-\mu_{B}\right) i_{D D}+\mu_{B} c_{R E S}\right]$ due to B's quasi-monopolistic power in its market. Reserves RES consist of reserves from incoming payments $(R I P)$ and borrowed reserves $(B R)$, which include reserves borrowed (wholesale) from other banks $(R W)$ and those borrowed from the central bank $(R C B)$, which reflects also the cost of holding collateral (safe and liquid) assets against potential cash borrowing needs.

Knowing that $i_{D D}<i_{T D}$, and noting that

$$
c_{R E S}=\frac{c_{R I P} R I P+c_{B R} B R}{R E S}
$$

where $c_{R I P}=0<i_{T D}$, and that

$$
c_{B R}=\frac{i_{R W} R W+i_{C B} R C B}{B R}<i_{T D}
$$

since the cost of borrowing reserves from the interbank market or intra-daily from the central bank is lower than the interest rate on term deposits, the following strict inequality holds:

$$
\left(1-\mu_{B}\right) i_{D D}+\mu_{B} c_{R E S} \ll i_{T D}
$$

that is, ceteris paribus, bank B's cost of liabilities is lower than that of pure intermediary I. Moreover, still under ceteris paribus conditions, since both are profit maximizers and the marginal cost of lending is lower for bank B than for pure intermediary I, the former will 
always be able to expand equilibrium lending beyond what is feasible for pure intermediary I, that is, $L_{B} \gg L_{I}$. Thus,

$$
\begin{aligned}
& \text { Commercial bank seigniorage }\left.\equiv \Pi_{B}\right|_{1>\sigma_{B}=\sigma_{I}>0}-\left.\Pi_{I}\right|_{1>\sigma_{I}=\sigma_{B}>0} \\
& \quad=\left\{i_{L} L_{B}-\left[\left(1-\mu_{B}\right) i_{D D}+\mu_{B} c_{R E S}\right] D D_{B}\right\}-\left\{i_{I} L_{I}-i_{T D} T D\right\} \gg 0
\end{aligned}
$$

that is, all else equal, money creation allows commercial banks to extract from the economy higher rents than (otherwise identical) pure financial intermediaries.

Importantly, here, the extra seigniorage extracted by banks is independent of their quasimonopolistic power and is only due to the effect of the scale factor on the banks' liabilities side. 


\section{ApPendix III - Commercial Bank Seigniorage And PAYMEnt Settlement SYSTEMS}

It is important to understand commercial bank seigniorage in the context of different types of payment settlement systems. In this appendix, following current practice worldwide, it is assumed that settlement of interbank payments takes place in central bank money (reserves). Since holding reserves carries an opportunity cost for banks (unless such reserves are remunerated at the same level as their best possible alternative option), the cost from holding reserves detracts from commercial bank seigniorage. As different payment settlement systems require banks - ceteris paribus - to mobilize different volumes of reserves, each type of system has a different impact on commercial bank seigniorage.

Take an economy with a central bank (CB), two banks (A, B), and four customers (a1, a2, b1, b2), where $\mathrm{a} 1$ and $\mathrm{a} 2$ are customers of bank $\mathrm{A}$ and $\mathrm{b} 1$ and $\mathrm{b} 2$ are customers of bank B. Banks $\mathrm{A}$ and $\mathrm{B}$ hold no reserves with $\mathrm{CB}$ initially. The case is analyzed where the same transactions are executed and settled in two different systems, respectively: i) a real-time gross settlement (RTGS) system and ii) a deferred netting settlement (DNS) system. ${ }^{35}$

\section{RTGS}

The following sequence takes place:

1. A lends $\$ 100$ to a1 (and creates an equal amount of deposits)

2. a1 pays $\$ 100$ to $b 1$

3. A borrows $\$ 100$ from $\mathrm{CB}$ and transfers $\$ 100$ to $\mathrm{B}$ : interbank settlement is done

4. B lends $\$ 150$ to b2 (and creates an equal amount of deposits)

5. b2 pays $\$ 150$ to a2

6. B receives $\$ 100$ from $A$ (item 3 above) and borrows $\$ 50$ from $\mathrm{CB}$

7. B pays $\$ 150$ to $\mathrm{A}$ : interbank settlement is done

8. A repays $\$ 100$ to $\mathrm{CB}$

9. B borrows $\$ 50$ from $\mathrm{A}$ and repays $\$ 50$ to $\mathrm{CB}$, or

\footnotetext{
${ }^{35}$ In RTGS systems transfer of money or securities takes place from one bank to another on a "real time" and on "gross" basis. Settlement in "real time" means payment transaction is not subject to any waiting period. The transactions are settled as soon as they are received and processed. Transactions are executed only if they are covered by sufficient liquidity. "Gross" settlement means that transactions are settled on a one to one basis without bundling or netting with any other transaction. Once executed, payments are final and irrevocable. In net settlement systems, credit and debit transactions are recorded on the clearinghouse books throughout the business day, and banks calculate the collective total of all transactions on any given day to be settled at the end of that day (or of a predefined settlement period during the day). Final settlement of the net transactions, the credits less the debits, occurs when funds due to a bank are credited to its settlement account.
} 
10. $\mathrm{B}$ renews its loan from $\mathrm{CB}$

At the end of the sequence, CB has issued $\$ 150$ intraday.

Under item 9 all $\$ 150$ reserves go to zero by end-of-day as A and B repay their loans to CB: no net central bank money (reserves) creation. Yet $\$ 250$ commercial bank money (demand deposits) were created, which supported $\$ 250$ worth of transactions.

Under alternative item 10 , the $\$ 50$ intraday loan converts into an overnight loan and becomes money supply: $\$ 50$ net reserves creation. But, as above, $\$ 250$ demand deposits were created by banks, which supported $\$ 250$ worth of transactions.

\section{DNS}

Assuming the same transactions take place in a NSS, it can be immediately seen here that the end-of-day balance to be settled between A and B is $\$ 50$, which B borrows from CB. Although this resembles item 10 above, netting in fact saves borrowing costs overall, since under RTGS total borrowing from $\mathrm{CB}$ is $\$ 150$ while under netting it is only $\$ 50$. Deposit creation and transactions are as above.

In both cases, commercial bank money has been created in excess of central bank money and has supported a correspondingly larger volume of (real and financial) transactions. As the demands for converting deposits into cash are limited, the greatest share of deposits created in excess of reserves remain in the system as such: this large mass of deposits outstanding (net of all conversions, destructions and new deposit creations) earn an ongoing flow of net revenues. These net revenues originate from the banks' exclusive power to create money (in excess of central bank money) and represent commercial bank seigniorage.

\section{Conclusion}

From the above examples it follows that commercial bank seigniorage ranges between a maximum value when money issuance is not constrained by the demand for reserves and a minimum of zero when money issuance is subjected to full reserves requirements (e.g., currency board, $100 \%$ reserve or narrow banking). In all intermediate cases, seigniorage takes on positive values.

As noted, commercial bank seigniorage is associated with the banks' power to create new money and must not be confused with the return on financial intermediation activities, which can only transfer pre-existing money from surplus units (typically savers) to deficit units (typically investors). 